\title{
LEVANTAMENTO DE ASPECTOS E IMPACTOS AMBIENTAIS EM UMA COOPERATIVA DE ENERGIA ELÉTRICA DO SUL CATARINENSE
}

CLEBER MARCON DE PIERI | UNISUL RAFAEL FEYH JAPPUR, Dr. | UFSC

\section{INTRODUÇÃO}

As Cooperativas de Eletrificação estão presentes no setor elétrico brasileiro há muito tempo contribuindo significativamente para o desenvolvimento rural e urbano e trazendo diversos benefícios para a sociedade. Porém, apesar dos benefícios que este sistema de cooperativas promove, o ciclo de vida da energia elétrica ocasiona diversos impactos ambientais que vão além dos impactos decorrentes da geração da energia elétrica, isso porque, para que a mesma chegue até as residências, é necessário também o processo de transmissão e distribuição, processos estes que precisam ter seus impactos conhecidos e avaliados a fim de que medidas de controle e prevenção possam ser propostas.

Diante da importância deste assunto e dos benefícios que um SGA traz para as empresas, em acordo com Barbieri (2011) e ABNT (2015), que este trabalho tem como objetivo identificar os aspectos e impactos ambientais em uma Cooperativa de Energia Elétrica do Sul Catarinense, além de propor oportunidade de melhoria para aspectos e impactos identificados que não possuem controle. Desta forma, busca-se com este trabalho contribuir para uma futura implementação de um SGA, em atendimento a ABNT NBR ISO 14001 na referida Cooperativa. A metodologia utilizada foi de uma pesquisa descritiva e estudo de caso, tendo uma abordagem qualitativa.

\section{RESULTADOS E DISCUSSÃO}

A Cooperativa de Energia Elétrica atende consumidores de quatro municípios do interior de Santa Catarina. Possui potência instalada de aproximadamente 38.932 KVA e 1500 quilômetros de redes de distribuição em alta e baixa tensão. A sede da empresa possui um galpão para almoxarifado medindo $230 \mathrm{~m}^{2}$, salas administrativas, cozinha, refeitório, além de baias para sucatas e a recuperação de materiais das de campo.
A partir do levantamento das atividades desenvolvidas pela empresa e, seguindo o procedimento metodológico apresentado neste estudo, fez-se então a elaboração da matriz de aspectos e impactos ambientais, com finalidade de identificar aqueles que são mais significativos.

Referente aos resultados verifica-se que existem na empresa um total de 55 ocorrências de aspectos que geram impactos ambientais. Do total de impactos levantados neste trabalho, dois são classificados como Nível I (alto), 10 são classificados como nível II (moderado) e 43 são classificados como nível III (baixo).

Todavia, 26 destes não possuem medida de controle, a saber: consumo de recursos naturais, geração de resíduos recicláveis e não recicláveis, geração de resíduos perigosos - Classe I, geração de resíduos orgânicos, geração de emissões gasosas e geração de resíduos de madeira; elaboraram-se propostas de medidas de controle.

\section{CONSIDERAÇÕES FINAIS}

Por meio desta pesquisa atingir objetivo da pesquisa, assim como agregou conhecimento junto aos colaboradores e lideranças da Cooperativa. Para finalizar, deixa-se como sugestão para trabalhos futuros, o levantamento dos requisitos que a empresa precisa cumprir para a implantação de um SGA em conformidade com a Norma ABNT ISO 14001:2015 e ampliação deste estudo para outras Cooperativas e diferentes segmentos produtivos.

\section{REFERÊNCIAS}

ABNT. NBR ISO 14001 - Sistemas de gestão ambiental: requisitos com orientações para uso. Rio de Janeiro. 2015.

BARBIERI, J.C. Gestão Ambiental Empresarial: Conceitos, Modelos e Instrumentos. 3. ed. São Paulo: Saraiva, 2011 
